\title{
A FUNÇÃO SOCIAL DOS IMÓVEIS URBANOS À LUZ DA CONSTITUIÇÃO FEDERAL DE 1988
}

\author{
Fabrício P. Weiblen ${ }^{1}$ \\ Jardel L. Vettorato \\ Tarso W. Tech \\ Marcelo S. da Silva
}

\begin{abstract}
RESUMO: O presente estudo visa a examinar questões referentes à função social da propriedade urbana como cláusula geral de natureza constitucional-principiológica, bem como, a partir da análise da legislação infra-constitucional e lições da doutrina, apresentar reflexões acerca dos mecanismos existentes para garantir sua efetivação. Dessa forma, estuda a finalidade social como princípio integrante e condicionante da estrutura do conceito de propriedade, partindo-se dos preceitos constitucionais até sua regulamentação municipal, evidenciando-se os aspectos atinentes aos imóveis urbanos.
\end{abstract}

PALAVRAS-CHAVE: função social, propriedade urbana, Estatuto da Cidade, Plano Diretor.

\section{The social rule of the urban realty before the Federal Constitution of 1988.}

\begin{abstract}
The present study intends to examine questions that refer to the social role of the urban property as a general clause with a constitutional-principled nature, and also, through the analysis of the sub-constitutional legislation and lections of the doctrine, present reflections about the existing mechanism to guarantee its effectuation. This way, it studies the social purpose as a principle which integrates and condition the structure of the property concept, beginning from the constitutional precepts to the municipality regulation, evidencing the aspects that refer to the urban realty.
\end{abstract}

KEY-WORDS: social rule, urban property, City Statute, Director Plan.

\section{INTRODUÇÃO}

O processo de urbanização no Brasil começou através de ondas migratórias do campo em direção às cidades, a partir dos anos 60, visto que muitos trabalhadores rurais abandonaram suas terras em busca de melhores condições de vida. Nessa esteira, atualmente, cerca de $80 \%$ da população brasileira vive nos centros urbanos, ou seja, o Brasil pode ser considerado um país urbanizado.

Desse modo, verifica-se que as cidades sofreram crescimento significante em curto período de tempo, razão pela qual tal crescimento se deu de forma desordenada, acompanhado de numerosos problemas, tais como má ocupação do solo, formação de favelas, ocupação de áreas particulares ou públicas de forma irregular, ausência de infra-estrutura de saneamento básico, saúde, educação e outros, que contribuíram para a atual realidade de caos urbano. Soma-se a isso o fato de que o país não possuía a devida previsão legislativa em relação à correta ocupação e utilização do solo urbano.

\footnotetext{
${ }^{1}$ Acadêmicos do Curso de Direito da UFSM.
}

(C) 2008. Departamento de Direito da UFSM. Todos os direitos reservados. 
Com a promulgação da Constituição Federal de 1988, contudo, esse cenário sofreu substanciais alterações. Os constituintes disciplinaram as diretrizes gerais referentes à política urbana nacional, com o viés de ordenar o pleno desenvolvimento da função social das cidades e garantir o bem-estar social de seus habitantes.

Neste liame, estabeleceu-se, no art. $5^{\circ}$, XII e XIII, da Carta Magna, que o direito de propriedade somente estará assegurado quando a propriedade atender a sua função social. Portanto, o livre uso, gozo, fruição da propriedade está condicionada ao cumprimento de tal função, sendo tal regra aplicada tanto à propriedade rural, quanto à propriedade urbana.

Em relação à propriedade rural, a $\mathrm{CF} / 88$ disciplinou que a propriedade que não atender a sua função social será passível de desapropriação, no mesmo sentido dispondo o Estatuto da Terra e a Lei 8.629/93, que trata da reforma agrária. Do mesmo modo, a $\mathrm{CF} / 88$ trouxe regras acerca da política nacional urbana e delegou aos Planos Diretores Municipais a competência exclusiva (art. 30, CF/88) para definir a função social da propriedade urbana de suas áreas territoriais.

Nesse contexto, em 2001, publicou-se a Lei 10.257/01 (Estatuto da Cidade), prescrevendo as diretrizes para a política e o desenvolvimento urbano, além das sanções às propriedades que não atenderem à função social, dentre as quais pode-se citar, por exemplo, o parcelamento, edificação ou utilização compulsórios, a aplicação do IPTU progressivo no tempo $\left(\operatorname{art} .7^{\circ}\right.$ ) e a possibilidade de desapropriação (art. $8^{\circ}$ ).

Neste norte, conforme a Constituição Federal, o imóvel urbano atenderá a sua função social quando cumprir as exigências fundamentais de ordenação da cidade expressa no plano diretor municipal. Ou seja, cabe ao plano diretor local traçar as diretrizes da função social da propriedade urbana no município, objetivando o bem-estar social da comunidade e também limitando a atuação do Poder Público.

Por essas palavras, conforme leciona Santos (2002, p. 139), “entende-se que há concretização da função social de propriedade quando a sua instituição jurídica serve de instrumento para a preservação da ordem de funcionamento prescrita pela sociedade, atuando de maneira integrada com as demais instituições jurídicas a ela correlacionadas".

Verifica-se, portanto, que incumbe à administração pública municipal desenvolver a política urbana e estabelecer os critérios para definir a função social da propriedade urbana no município.

(C) 2008. Departamento de Direito da UFSM. Todos os direitos reservados. 


\section{A COMPETÊNCIA DELEGADA AOS MUNICÍPIOS PARA GERIR A POLÍTICA URBANA}

Diante dos sérios problemas urbanos ocasionados pela ausência de marcos de regulamentação, o legislador constituinte delegou com exclusividade aos municípios a competência de gerir a política urbana municipal a fim de proporcionar aos cidadãos o bem-estar de seus habitantes. Tal atribuição se deve, em parte, às substanciais alterações que ocorreram com a promulgação da carta constitucional de 1988.

A Constituição Federal de 1988 promoveu inúmeras alterações e inovações na ordem normativa do país. Além dos grandiosos e perspicazes avanços no que diz respeito aos direitos e garantias fundamentais e aos direitos sociais e políticos, a carta magna inovou acerca do tratamento dado aos municípios, uma vez que impunha a estrutura federativa do país colocando estes na posição de federados.

A partir de 1988, o município passou a receber o tratamento, isto é, o status de ente federativo da República Federativa do Brasil. Antes disso, o município era regido por leis estaduais, não possuindo autonomia administrativa, financeira e política que atualmente goza. A respectiva alteração surtiu efeitos em várias áreas da sociedade, sendo amplamente defendida por variados publicistas, dentre eles Hely Lopes Meirelles (2007) que comenta da seguinte forma acerca de tal mudança:

O Município brasileiro é entidade estatal integrante da federação. Essa integração é uma peculiaridade nossa, pois em nenhum outro Estado Soberano se encontra o Município como peça do regime federativo constitucionalmente reconhecida. Dessa posição singular do nosso município é que resulta sua autonomia político-administrativa, diversamente do que ocorre nas demais Federações, em que os Municípios são circunscrições territoriais meramente administrativas. (MEIRELLES, ANO, p. 145).

Destarte, afirma o artigo $1^{\text {a }}$ da carta magna, que a República federativa do Brasil é formada pela união indissolúvel dos Estados e Municípios e do Distrito Federal. Daí por que claramente se evidencia o tratamento concedido aos Municípios, ou seja, foram erigidos ao status de ente federado, parte da estrutura federativa brasileira, dotado de autonomia administrativa, política e financeira. 
Do mesmo modo, verifica-se o status de ente federado concedido ao Município da leitura do caput do artigo 18, que trata da organização político-administrativa da República Federativa do Brasil:

Art. 18. A organização político-administrativa da República Federativa do Brasil compreende a União, os Estados, o Distrito Federal e os Municípios, todos autônomos, nos termos desta Constituição.

$\S 1^{\circ}$ - Brasília é a Capital Federal.

$\S 2^{\circ}$ - Os Territórios Federais integram a União, e sua criação, transformação em Estado ou reintegração ao Estado de origem serão reguladas em lei complementar.

$\S 3^{\circ}$ - Os Estados podem incorporar-se entre si, subdividir-se ou desmembrarse para se anexarem a outros, ou formarem novos Estados ou Territórios Federais, mediante aprovação da população diretamente interessada, através de plebiscito, e do Congresso Nacional, por lei complementar.

$\S 4^{o}$ A criação, a incorporação, a fusão e o desmembramento de Municípios, far-se-ão por lei estadual, dentro do período determinado por Lei Complementar Federal, e dependerão de consulta prévia, mediante plebiscito, às populações dos Municípios envolvidos, após divulgação dos Estudos de Viabilidade Municipal, apresentados e publicados na forma da lei. (Redação dada pela Emenda Constitucional n $n^{\circ}$ 15, de 1996).

Em síntese, o Município deve gerir a própria política, tendo em vista as peculiaridades encontradas nos mais variados territórios brasileiros.

Além disso, a autonomia dos Municípios ficou esculpida no artigo 29 da Constituição Federal $^{2}$ ratificando expressamente o teor dos artigos $1^{\mathrm{a}}$ e $18^{\mathrm{a}}$ ao disciplinar que os Municípios reger-se-ão por Lei Orgânica própria. Diante disso, as administrações municipais receberam maior flexibilidade para delinear as políticas locais conforme as peculiaridades municipais.

Nas palavras de Silva (2005) a autonomia possui como significado a capacidade ou poder de gerir os próprios negócios, ou seja, aos administradores municipais foi delegada a competência de articularem os negócios do Município de acordo com a realidade e necessidade local, dentro de um círculo prefixado por entidade superior e a CF que se apresenta como distribuidor de competências exclusivas entre as três esferas de governo. O mesmo autor ainda aborda a posição privilegiada dada aos Municípios, que derivaria de quatro capacidades: a de auto-organização; a de autogoverno; a normativa própria; e, por fim, a capacidade de auto-administração.

\footnotetext{
${ }^{2}$ Art. 29: O Município reger-se-á por lei orgânica, votada em dois turnos, com o interstício mínimo de dez dias, e aprovada por dois terços dos membros da Câmara Municipal, que a promulgará, atendidos os princípios estabelecidos nesta Constituição, na Constituição do respectivo Estado e os seguintes preceitos.
}

(C) 2008. Departamento de Direito da UFSM. Todos os direitos reservados. 
Neste sentido as competências municipais foram delineadas no artigo 30 da magna carta. O dispositivo constitucional enumera todas as atribuições delegadas com exclusividade aos Municípios:

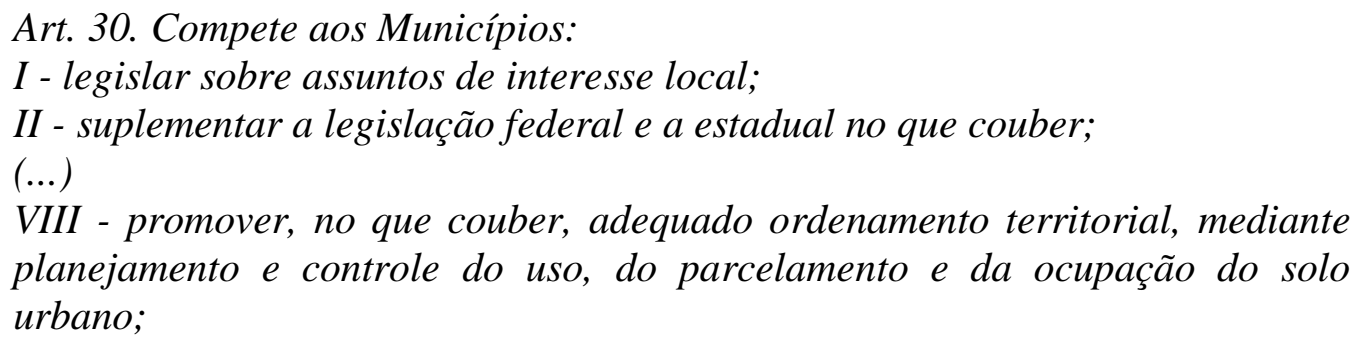
urbano;

Conforme Meirelles (2007), a autonomia do Município brasileiro está assegurada na Constituição da República para todos os seus assuntos de interesse local (art. 30) e se expressa sob o tríplice aspecto político (composição efetiva do governo e da dição de normas locais), administrativo (organização e execuão dos serviços públicos locais) e financeiro (decretação, arrecaação, e aplicação dos tributos municipais).

Diante disso, aos Municípios coube a responsabilidade de gerir toda a política urbana, no intuito de encontrar mecanismo e soluções para mitigar o atual caos urbano das cidades brasileiras. Mais recentemente, o processo de ampliação da autonomia municipal foi instrumentalizado com a promulgação da Lei Federal de 10.257/01, o Estatuto da Cidade, que enumera as ferramentas que devem ser utilizadas pelos Municípios a fim de possibilitar a intervenção de modo mais abrangente e efetivo dentro da política urbana municiapal.

Neste liame, menciona o Estatuto da Cidade que cabe ao Municipio elaborar Plano Diretor próprio que atenda as suas particularidades. Outrossim, cabe aos Municípios definir de que modo a propriedade urbana deve atender a sua função social, conforme preconiza o inciso XXIII do artigo $5^{\mathrm{a}}$ da Constituição Federal. Portanto, o uso da propriedade urbana passou a ser definido conforme os interesses sociais locais.

O Estatuto da Cidade, ligado à autonomia delegada aos Munípios pela carta constitucional, é um marco do processo de transformação e modernização da Administração Pública. As repercussões sociais decorrentes deste novo panorama 
legislativo serão objetos propulsores para instaurar um novo modelo de planejamento urbano do Brasil ${ }^{3}$.

\section{A RELATIVIZAÇÃO DO DIREITO DE PROPRIEDADE URBANA NA CONSTITUIÇÃO DE 1988}

A Constituição Federal de 1988 visou a relativizar o direito de propriedade, através da exigência do cumprimento da função social do imóvel. Essa intervenção na propriedade privada preconizada pela Carta Magna objetiva satisfazer os interesses da coletividade, em detrimento aos proprietários que não dão uma utilidade social a seus imóveis rurais ou urbanos.

O cumprimento e a fiscalização da função social nos imóveis urbanos é competência municipal. Assim, a Constituição Federal, em seu artigo 182, § $2^{\circ}$, determina: "a propriedade urbana cumpre sua função social quando atende as exigências fundamentais de ordenação da cidade expressas no plano diretor". Ainda, a própria Constituição estabelece que o Plano Diretor "é o instrumento básico da política de desenvolvimento e de expansão urbana" e que a propriedade urbana cumpre sua função social quando atende às exigências neste expressas.

Por fim, o próprio artigo 182 da CF exige que as desapropriações deverão ser feitas mediante justa e prévia indenização em dinheiro e o $\S 4^{\circ}$ do artigo supracitado delega aos municípios, de forma taxativa, as seguintes atribuições:

I - parcelamento ou edificação compulsória;

II - imposto sobre a propriedade predial e territorial urbana progressivo no tempo;

III - desapropriação com pagamento mediante títulos da dívida pública de emissão previamente aprovada pelo Senado Federal, com prazo de resgate de até dez anos, em parcelas anuais, iguais e sucessivas, assegurados o valor real da indenização e os juros legais.

No mesmo sentido, o Estatuto da Cidade (Lei 10.257/01), em seus artigos $6^{\circ}, 7^{\circ}$ e $8^{\circ}$, traz as exigências genéricas que as leis de cada município deverão conter, a respeito do tratamento a ser dado pelo Poder Público municipal às propriedades subutilizadas ou não utilizadas, os aspectos gerais do procedimento administrativo a ser

\footnotetext{
${ }^{3}$ PORTAL Wikipedia. Disponível em < http://pt.wikipedia.org/wiki/Munic\%C3\%ADpio>. Acessado em 24 de junho de 2008.

(C) 2008. Departamento de Direito da UFSM. Todos os direitos reservados.
} 
adotado nestas situações, a aplicação do Imposto Territorial da Propriedade Urbana de forma progressiva no tempo e, por fim, a medida extrema de desapropriação do imóvel que não cumpra sua função social.

Da análise das normas constitucionais e do Estatuto da Cidade, constata-se uma importante atribuição concedida ao Poder Público municipal, tornando-o a entidade competente para efetivar o cumprimento da função social na área urbana. Este poder conferido aos municípios é de suma importância na viabilização de um Estado Federativo com poderes menos concentrados, uma vez que a aglutinação destes no ente federal tornaria ineficaz a fiscalização e o cumprimento efetivo da exigência de que todos os imóveis devem estar cumprindo sua função social.

Assim, o Plano Diretor é uma ferramenta legal de suma importância para o desenvolvimento e expansão de forma adequada do município de Santa Maria, especialmente na complexa matéria de regular a função social dos imóveis de sua zona urbana.

\section{OS MECANISMOS INTRODUZIDOS PELO ESTATUTO DA CIDADE PARA A EFETIVAÇÃO DA FUNÇÃO SOCIAL DA PROPRIEDADE}

A Lei 10.257 representa um verdadeiro marco no desenvolvimento da política urbanística do Brasil. Vários e importantes instrumentos foram criados pelo Estatuto da Cidade com o objetivo de que as cidades se desenvolvam de forma mais organizada, democrática, visando ao bem-estar coletivo e ao equilíbrio ambiental, tudo em conformidade com a exigência constitucional da finalidade social dos imóveis urbanos.

\subsection{Instrumentos do Estatuto da Cidade Obrigatórios no Plano Diretor}

Conforme preceitua o artigo 42 do Estatuto da Cidade, existem instrumentos básicos que devem ser obrigatoriamente adotados nos Planos Diretores municipais.

Art. 42. O plano diretor deverá conter no mínimo:

I - a delimitação das áreas urbanas onde poderá ser aplicado o parcelamento, edificação ou utilização compulsórios, considerando a existência de infraestrutura e de demanda para utilização, na forma do art. 5 o desta Lei;

II - disposições requeridas pelos arts. 25, 28, 29, 32 e 35 desta Lei;

III - sistema de acompanhamento e controle. 
Os institutos referidos no artigo acima objetivam dar a cidade a sua função social, especialmente no que se refere às suas propriedades urbanas.

Assim, a delimitação de áreas urbanas para a aplicação do parcelamento, edificação ou utilização compulsórios importa em forçar o proprietário de imóvel não edificado, subutilizado ou não utilizado da dar uma destinação social à sua propriedade. Desta forma, ALMEIDA (2002, p. 42) assevera que "a propriedade deixa de ser direito subjetivo do proprietário para converter-se em função social do possuidor da riqueza”.

Os instrumentos referidos no inciso II do artigo 41 referem-se, respectivamente, ao direito de preempção, outorga onerosa do direito de construir, possibilidade de alteração do uso do solo, operações urbanas consorciadas e transferência do direito de construir.

O direito de preempção confere ao Poder Público municipal, pelo prazo limitado de 5 anos, a preferência para adquirir imóveis urbanos sujeitos a alienações, desde que a área em que esteja situado o bem seja necessária para finalidades urbanísticas especificadas no artigo 26 do Estatuto da Cidade (rol taxativo).

A outorga onerosa do direito de construir importa no benefício ao proprietário de construir acima do coeficiente básico de aproveitamento dos terrenos edificáveis ${ }^{4}$, previsto em lei. Como o próprio nome sugere, deve, o titular do domínio, pagar uma contrapartida para o Poder Público para adquirir este direito.

A alteração do uso do solo é outro instrumento que busca beneficiar o dono do imóvel. Através dele, permite-se que o proprietário use o solo de uma maneira diversa daquela prevista nas leis municipais (Lei de Zoneamento ou de Ocupação do Solo), desde que também pague por isso.

A disciplina, os valores e as formas de pagamento, bem como as isenções inerentes aos institutos da outorga onerosa do direito de construir e da alteração do uso do solo dependem de lei específica municipal, que deve estar em conformidade com o Plano Diretor.

Outra importante ferramenta na busca de desenvolvimento urbano voltado para o social e obrigatório nos planos diretores são as operações urbanas consorciadas. Através deste mecanismo, possibilita-se que Estado e a iniciativa privada associem-se na busca de desenvolver ou melhorar determinadas regiões urbanas.

\footnotetext{
${ }^{4}$ Coeficiente de aproveitamento é a relação entre a área edificável e a área do terreno.

(C) 2008. Departamento de Direito da UFSM. Todos os direitos reservados.
} 
As operações podem destinar-se a alterações nos índices e características de parcelamento, uso e ocupação do solo, bem como modificações em normas edilícias, sempre em conformidade com a legislação ambiental. Também têm a importante função de regularizar construções e modificações irregulares nos imóveis, aplicando-se principalmente nas áreas residências das camadas mais pobres da cidade ${ }^{5}$. O instituto das operações consorciadas, conforme determinado na própria Lei 10.257 , objetiva a transformação de áreas urbanísticas estruturais, melhorias sociais e valorização ambiental.

Por fim, é obrigatório nos planos urbanísticos municipais o mecanismo da transferência do direito de construir. Neste sentido, lei municipal específica pode determinar que o proprietário edifique em local distinto daquele em que se situa seu imóvel ou alienar sua propriedade quando a mesma for considerada necessária para finalidades urbanísticas determinadas no artigo 35 do Estatuto da Cidade. ${ }^{6}$

Importante ressaltar que estes instrumentos de política urbana criados pelo Estatuto da Cidade, além de estarem em conformidade com o plano diretor de cada município, devem ser disciplinados em lei municipal específica. Estas leis visam à adaptação dos referidos institutos às peculiaridades de cada cidade.

\subsection{Outros Instrumentos Inovadores do Estatuto da Cidade}

Além dos mecanismos mínimos que devem estar presentes nos planos diretores, o Estatuto da Cidade criou outras ferramentas relevantes na busca de garantir as funções sociais das cidades, principalmente no que se refere à adequação do direito de propriedade às necessidades urbanísticas de ocupação dos espaços habitáveis.

Neste viés, a Lei 10.257 criou sanções aos proprietários de bens que não cumprem suas funções sociais. Entre elas, merecem destaque a aplicação do IPTU progressivo no tempo e a desapropriação para fins urbanísticos.

\footnotetext{
${ }^{5}$ Esta regra pode incentivar o aumento de imóveis irregulares, uma vez que os proprietários tem a possibilidade de serem beneficiados posteriormente pelas operações urbanas consorciadas.

${ }^{6}$ Art. 35. Lei municipal, baseada no plano diretor, poderá autorizar o proprietário de imóvel urbano, privado ou público, a exercer em outro local, ou alienar, mediante escritura pública, o direito de construir previsto no plano diretor ou em legislação urbanística dele decorrente, quando o referido imóvel for considerado necessário para fins de:

I - implantação de equipamentos urbanos e comunitários;

II - preservação, quando o imóvel for considerado de interesse histórico, ambiental, paisagístico, social ou cultural;

III - servir a programas de regularização fundiária, urbanização de áreas ocupadas por população de baixa renda e habitação de interesse social.
}

(C) 2008. Departamento de Direito da UFSM. Todos os direitos reservados. 


\subsubsection{O IPTU progressivo no tempo}

A aplicação do IPTU $^{7}$ com alíquotas progressivas no tempo é uma medida que visa coibir o proprietário que não dá a seu imóvel uma destinação adequada aos interesses sociais. Tal instituto só deve ser aplicado se não forem cumpridas, nos prazos prescritos no artigo $5^{\circ}$ do Estatuto da Cidade, se as exigências da administração pública de parcelar, edificar ou utilizar compulsoriamente o solo urbano não edificado, subutilizado ou não utilizado. Isto significa que somente será legítima a aplicabilidade da sanção após o descumprimento da referida obrigação.

A medida fundamenta-se no artigo $182, \S 4^{\circ}$, II da Carta Magna e está prevista no artigo $7^{\circ}$ da Lei 10.257:"Em caso de descumprimento das condições e dos prazos previstos na forma do caput do art. 5ำ desta Lei, ou não sendo cumpridas as etapas previstas no $\S 5^{\circ}$ do art. $5^{\circ}$ desta Lei, o Município procederá à aplicação do imposto sobre a propriedade predial e territorial urbana (IPTU) progressivo no tempo, mediante a majoração da alíquota pelo prazo de cinco anos consecutivos". Há que se salientar que tal comando legal deve, ainda, ser regulamentada por lei municipal específica

Denota-se que a cobrança do IPTU progressivo no tempo tem caráter extrafiscal. Por esta afirmação entenda-se que o referido instituto não tem a finalidade exclusiva de arrecadação em benefício da municipalidade. $\mathrm{O}$ aumento da alíquota do imposto visa a justamente compelir o dono do imóvel a dar uma finalidade social para o mesmo.

Muito se discutiu na doutrina e jurisprudência a respeito da constitucionalidade de progressividade de imposto. Conforme reiteradas decisões no Supremo Tribunal Federal toda e qualquer aplicação de progressividade do IPTU será absolutamente inconstitucional, salvo quando amparadas no artigo $156, \S 1^{\circ}, \mathrm{I}^{8}$ e no $\S 4^{\circ}$ do artigo 182 , ambos da Constituição.

Cabe ressaltar que, embora os dois artigos da Carta Magna mencionados acima prevejam a progressividade do IPTU, trata-se de institutos com fundamentos totalmente distintos. Enquanto que o artigo 156, $\S 1^{\circ}$, I refere-se exclusivamente a progressividade em razão do valor do imóvel, o artigo 182, § $4^{\circ}$ destina-se a punir o não cumprimento da função social em virtude de descumprimento de obrigação imposta pelo Pode Público.

\footnotetext{
${ }^{7}$ Imposto sobre a propriedade predial e territorial urbana.

${ }^{8}$ Art. 156. Compete aos Municípios instituir impostos sobre:

I - propriedade predial e territorial urbana;

$\S 1^{\circ}$ Sem prejuízo da progressividade no tempo a que se refere o art. $182, \S 4^{\circ}$, inciso II, o imposto previsto no inciso I poderá:

I - ser progressivo em razão do valor do imóvel; e

II - ter alíquotas diferentes de acordo com a localização e o uso do imóvel.
}

(C) 2008. Departamento de Direito da UFSM. Todos os direitos reservados. 
Nas palavras de Almeida (2002, p. 61), “...a progressividade das alíquotas do IPTU como sanção pelo não-atendimento da função social da propriedade não guarda relação com o valor do imóvel.”.

O mesmo autor faz mais uma diferenciação quanto aos dois institutos. Enquanto que a progressão do IPTU em razão do valor do imóvel ocorre uma única vez, o outro instituto (previsto no Estatuto da Cidade) tem a progressão do IPTU majorada com o passar do tempo, até que se cumpra a obrigação.

A aplicação do IPTU progressivo no tempo com finalidades urbanísticas também apresenta limitações em relação ao Poder Público. O valor da progressão fixado no ano posterior não poderá ser superior ao dobro do fixado no ano anterior, respeitada sempre a alíquota máxima de $15 \%$ e o prazo máximo de majoração de 5 anos consecutivos. Aqui, mais uma vez foi delegada competência aos municípios, cabendo a eles fixarem os percentuais de aumento anual das alíquotas, desde que observadas todas as limitações impostas na Lei 10.257.

\subsubsection{A desapropriação para fins urbanísticos com pagamento de títulos}

O Estatuto da Cidade, em conformidade com o artigo 182, III da Constituição Federal, criou nova forma de desapropriação totalmente distinta daquelas já existentes no ordenamento brasileiro. Assim, determina o artigo $8^{\circ}$ da Lei 10.257:

Art. $8^{\circ}$ Decorridos cinco anos de cobrança do IPTU progressivo sem que o proprietário tenha cumprido a obrigação de parcelamento, edificação ou utilização, o Município poderá proceder à desapropriação do imóvel, com pagamento em títulos da dívida pública.

§ lo Os títulos da dívida pública terão prévia aprovação pelo Senado Federal e serão resgatados no prazo de até dez anos, em prestações anuais, iguais e sucessivas, assegurados o valor real da indenização e os juros legais de seis por cento ao ano.

$\S 20$ O valor real da indenização:

I - refletirá o valor da base de cálculo do IPTU, descontado o montante incorporado em função de obras realizadas pelo Poder Público na área onde o mesmo se localiza após a notificação de que trata o \$2o do art. 50 desta Lei;

II - não computará expectativas de ganhos, lucros cessantes e juros compensatórios.

$\S 3$ o Os títulos de que trata este artigo não terão poder liberatório para pagamento de tributos.

$\S 4$ o Município procederá ao adequado aproveitamento do imóvel no prazo máximo de cinco anos, contado a partir da sua incorporação ao patrimônio público. 
§5 O aproveitamento do imóvel poderá ser efetivado diretamente pelo Poder Público ou por meio de alienação ou concessão a terceiros, observando-se, nesses casos, o devido procedimento licitatório.

$\S 6$ o Ficam mantidas para o adquirente de imóvel nos termos do $\S 50$ as mesmas obrigações de parcelamento, edificação ou utilização previstas no art. 5 o desta Lei.

Trata-se de uma desaprorpiação-sanção com finalidade urbanística, objetivando expropriar o imóvel do proprietário que não dá àquele bem uma finalidade social. Pelo exposto, nota-se que o fundamento desta expropriação difere das desapropriações por utilidade ou necessidade pública (art. $5^{\circ}$ do Dec. lei 3.365/41) ou interesse social (art. $2^{\circ}$ da Lei 4.132/62). Inobstante isso, as regras já existentes sobre desapropriações nas legislações anteriores poderão ser aplicadas de forma subsidiária para a desapropriação prevista no Estatuto da Cidade, desde que aquelas não contrariem esta.

Após o detalhamento da fundamentação e dos objetivos do instituto, faz-se necessário discorrer sobre a aplicabilidade do instituto. Conforme se analisa no artigo $8^{\circ}$ da Lei 10.257, o processo desapropriação pode ser feito desde que transcorridos 5 anos de aplicação da sanção do IPTU progressivo no tempo sem a implementação da obrigação determinada pelo artigo $5^{\circ}$ da mesma lei. Ou seja, a expropriação com o objetivo de dar uma finalidade social para imóveis urbanos é uma faculdade (poder discricionário) do Município que pode ser exercida depois de transcorridos os cinco anos.

Pondera-se que apesar de o instituto caracterizar-se por uma desapropriaçãosanção, o proprietário que sofrer a constrição terá direito à justa indenização. A penalidade está justamente na maneira de pagamento: mediante títulos da dívida pública, com aprovação prévia do Senado Federal e resgatáveis no prazo de até 10 anos.

A emissão prévia do Senado Federal também representa uma limitação aos municípios. Segundo Almeida (2002, p. 72), “...a decisão do município de desapropriar com pagamento em títulos encontra eventual limite na aprovação de emissão dos títulos pelo Senado Federal."

$\mathrm{O} \S 4^{\circ}$ do artigo $8^{\circ}$ do Estatuto da Cidade obriga o Poder Público municipal que efetuou a desapropriação a dar ao imóvel expropriado a devida função social, num prazo não superior a 5 anos da incorporação do bem ao patrimônio do município. Trata-se de previsão importante, uma vez que limita abusos que também poderiam ser praticados 
pela Administração. Assim, o novo proprietário (Município) tem a mesma obrigação que o antigo proprietário não cumpriu, qual seja, dar ao imóvel uma função social.

A finalidade social determinada pela lei pode ser feita diretamente pelo Poder Público oi mediante alienação a terceiros, com observância da Lei de Licitações. Eventuais terceiros adquirentes, obviamente, também estão obrigados a cumprir as obrigações de parcelar, edificar ou utilizar o imóvel.

Almeida (2002) faz importante ressalva no sentido de que se houve desapropriação porque o antigo dono não deu uma destinação social ao seu imóvel, e o Município também não cumpre com esta obrigação, preferível que o bem retorne ao expropriado, prevalecendo, nesta situação, o direito constitucional de propriedade.

\subsubsection{O usucapião especial de imóvel urbano}

Outro importante instrumento de política urbana que procura auxiliar na organização dos espaços habitáveis das cidades e na efetivação da função social dos imóveis é a usucapião especial de imóvel urbano. Trata-se de instituto jurídico moderno criado pela Constituição Federal de 1988 e regulado no Estatuto da Cidade.

A usucapião especial de imóvel urbano é forma aquisitiva da propriedade e tem como fundamento o direito constitucional à moradia dos integrantes das cidades. Percebe-se no instituto uma preocupação social, principalmente no que se refere aos imóveis ocupados por populações de baixa renda.

Este viés de efetivar o direito à moradia dos cidadãos mais pobres, que infelizmente são maioria nos grandes centros urbanos, apresenta total conformidade com os princípios constitucionais da cidadania e da dignidade da pessoa humana (artigo $1^{\mathrm{o}}$ da $\mathrm{CF}$ ) e com os fundamentos constitucionais de justiça, solidariedade e erradicação da pobreza e das desigualdades sociais (artigo $3^{\circ}$ da $\mathrm{CF}$ ).

A Carta da República prevê no artigo 183 a usucapião especial de imóvel urbano e a Lei 10.257 regula o instrumento dos artigos $9^{\circ}$ ao 14 do diploma legal. Assim, a Constituição determina os requisitos para a declaração da usucapião especial de imóvel urbano, que foram reproduzidos de maneira idêntica no Estatuto da Cidade.

Art. 183. Aquele que possuir como sua área urbana de até duzentos e cinqüenta metros quadrados, por cinco anos, ininterruptamente e sem oposição, utilizando-a para sua moradia ou de sua família, adquirir-lhe-á o domínio, desde que não seja proprietário de outro imóvel urbano ou rural. 
$\S 1^{\circ} O$ título de domínio e a concessão de uso serão conferidos ao homem ou à mulher, ou a ambos, independentemente do estado civil.

$\S 2^{\circ}$ Esse direito não será reconhecido ao mesmo possuidor mais de uma vez.

$\S 3^{\circ}$ Os imóveis públicos não serão adquiridos por usucapião.

Pela simples leitura do artigo, verifica-se que toda e qualquer pessoa que morar em imóvel urbano com finalidade de moradia sua ou para sua família, pelo período de 5 anos contínuos e sem oposição, adquire a propriedade do bem. Todavia, o instituto apresenta algumas limitações, justamente com o viés de ser utilizado apenas em benefício da população de baixa renda: o imóvel submetido a esta forma de usucapião não pode ser superior a 250 metros quadrados e o adquirente não pode ser proprietário de outro imóvel ou já ter sido beneficiado o por esta espécie de usucapião.

Estas limitações também têm o objetivo de evitar que os imóveis sejam submetidos aos interesses de especuladores, que poderiam adquirir propriedades através do referido mecanismo, em total violação aos princípios urbanísticos e da função social da propriedade.

Analisados os requisitos configuradores da usucapião especial de imóvel urbano, se faz necessárias algumas ponderações a respeito do instituto. Discutiu-se na doutrina e jurisprudência se o requisito de a propriedade não poder exceder a 250 metros quadrados referia-se ao terreno ou a área construída. Todavia, não há razão para maiores discussões, uma vez que o legislador foi expresso ao afirmar que a limitação de 250 metros quadrados aplica-se à área ou à edificação. Assim, prevalece o que for maior (terreno ou área construída) para fins de verificação no caso concreto da ocorrência desta exigência da usucapião.

Outra discussão desenvolveu-se a respeito do critério adotado para a determinação do imóvel como sendo urbano ou rural. Assim como na polêmica que existia a respeito do critério para a incidência do IPTU nos imóveis, a doutrina discutia se o critério para definir as propriedades como sendo urbanas era a localização ou a destinação das mesmas.

Também não resta maiores dúvidas quanto a este tema. Basta a análise dos princípios urbanísticos trazidos na Constituição e na Lei 10.257. O objetivo destas legislações foi o de proporcionar o desenvolvimento dos centros urbanos, densamente povoados, através de uma forma mais ordenada, visando a evitar ou mitigar o caos atual encontrado em diversas cidades. Do exposto, conclui-se que o critério utilizado pela lei para a classificação dos imóveis como urbanos foi o da localização. 
Existe uma sub-espécie de usucapião especial de imóvel urbano criada pelo Estatuto da Cidade que apresenta tão ou mais relevância do que aquela elencada na Constituição e já abordada no presente trabalho: trata-se da usucapião especial coletiva de imóvel urbano. O instrumento é destinado principalmente para regularizar a situação de grande parte da população que reside em zonas urbanas irregulares e de grande pobreza, como as favelas brasileiras.

Os requisitos e fundamentos são semelhantes aos exigidos na forma de aquisição de propriedade abordada anteriormente (interesse social e direito à moradia). Todavia, exige-se que a área usucapienda seja utilizada de forma coletiva por população de baixa renda para fins de moradia. Ou seja, por um número considerável de pessoas reconhecidamente pobres que residam naquele local.O imóvel também deve ter obrigatoriamente dimensões superiores a 250 metros quadrados.

Horbach (2001) evidencia outra distinção da usucapião de imóvel urbano para fins de moradia de pessoa ou de família em relação à usucapião coletiva; nesta última não se exige que entre os compossuidores beneficiados pela usucapião não tenha nenhuma pessoa que já tenha adquirido outra propriedade através de usucapião coletiva de imóveis urbanos. Porém, mesmo na forma coletiva de aquisição de propriedade, exige-se que nenhum dos possuidores seja proprietário de outro imóvel urbano ou rural.

A sentença que declarar a usucapião especial coletiva de imóvel urbano formará um condomínio indivisível entre os beneficiários, instituindo frações ideais aos compossuidores.

\section{A IMPORTÂNCIA DO PLANO DIRETOR COMO INSTRUMENTO URBANÍSTICO}

O Plano Diretor é um instrumento de urbanização inserido no planejamento municipal que estabelece a política de desenvolvimento e expansão urbana. Ele deve identificar e analisar as características físicas, as atividades predominantes e as vocações da cidade, bem como seus problemas e potencialidades. É um conjunto de regras e técnicas básicas que determinam o que pode e o que não pode ser feito em cada parte de cidade.

Trata-se de uma ferramenta democrática, uma vez que nasce de discussão pública que analisa e avalia a cidade, suas características, problemas e peculiaridades

(C) 2008. Departamento de Direito da UFSM. Todos os direitos reservados. 
para viabilizar a formulação do modelo de município desejado pela população. Noutras palavras, ocupa-se de temas da cidade e do meio rural, incluindo suas relações com municípios vizinhos, procurando um ambiente físico e social próspero e saudável: “O papel institucional reservado aos planos diretores e o crescente interesse real por sua elaboração e implantação, recupera-os como importantes instrumentos para o desenvolvimento social econômico e ambiental."(DEL RIO, Vicente apud TOBA, Marcos Maurício p. 162).

Desta forma, a prefeitura em conjunto com a sociedade, conforme preceitua o artigo 40, $\S 4^{\circ}$, do Estatuto da Cidade, busca direcionar o desenvolvimento da cidade de maneira coletiva e tendo como metas uma melhor qualidade de vida e a preservação dos recursos naturais. Vejamos:

Art. 40. O plano diretor, aprovado por lei municipal, é o instrumento básico da política de desenvolvimento e expansão urbana.

(...)

$\S 4$ o No processo de elaboração do plano diretor e na fiscalização de sua implementação, os Poderes Legislativo e Executivo municipais garantirão:

I - a promoção de audiências públicas e debates com a participação da população e de associações representativas dos vários segmentos da comunidade;

II - a publicidade quanto aos documentos e informações produzidos;

III - o acesso de qualquer interessado aos documentos e informações produzidos.

O Plano Diretor deve, portanto, ser discutido de forma democrática, através de audiências públicas e debates com a plena participação da população, aprovado pela Câmara de Vereadores e sancionado pelo prefeito. O resultado, formalizado como Lei Municipal, é a expressão do pacto firmado entre a sociedade e os poderes Executivo e Legislativo, sendo obrigação do Município publicizar os documentos referentes ao plano diretor e garantir a qualquer cidadão o livre acesso a esses documentos ou informações produzidos.

O plano diretor, conforme José Afonso da Silva (2000), compõe-se de três aspectos distintos: aspecto físico, aspecto social e aspecto administrativo-institucional. Pelo aspecto físico compreende-se se a ordenação do solo municipal; o aspecto social refere-se à melhoria da qualidade de vida da população local através da transformação dos espaços habitáveis; e o aspecto administrativo-institucional determina que o plano deve ter meios institucionais para ser implementado e aperfeiçoado constantemente, 
visto que não se trata de uma ferramenta rígida e deve ser alterado conforme as novas necessidades da cidade.

O mesmo autor cita que a função essencial de qualquer Plano Diretor é sistematizar o desenvolvimento físico, econômico e social do Município, visando ao bem-estar da comunidade local e sempre em conformidade com a função pública do urbanismo.

O Plano Diretor Municipal tem, ainda, uma importante tarefa, a qual está prevista no artigo $182, \S 2^{\circ}$, da Constituição Federal $^{9}$ e regulada genericamente em diversos dispositivos do Estatuto da Cidade. Trata-se da composição de interesses urbanísticos entre os proprietários de imóveis urbanos e o interesse público. Dessa forma, é de fundamental importância que o município trace em seu Plano Diretor os requisitos para o imóvel urbano cumprir sua função social e os instrumentos de fiscalização e de sanção aos proprietários que não dão aos seus imóveis uma destinação de interesse público.

\section{CONSIDERAÇÕES FINAIS}

A partir da crescente urbanização do país, verificou-se a presença de inúmeros problemas causados pelo crescimento desordenado das cidades. Em decorrência de tal realidade, tornou-se necessário ter a propriedade como um direito direcionado ao bem comum, de forma a amenizar as injustiças existentes.

Assim, a Constituição Federal de 1988 trouxe insculpida em seu texto uma cláusula principiológica acerca da finalidade social da propriedade, tanto urbana como rural, sendo que esta cláusula, assim como impõe ao proprietário um não-fazer, como, por exemplo, não poluir, estabelece um dever de exploração e destinação sócioeconômica ao bem, logo, podendo-se dizer que apresenta um aspecto passivo e um ativo. Desse modo, constata-se que a função social não se trata de uma simples limitação ao direito de propriedade, mas sim faz parte da estrutura deste.

\footnotetext{
${ }^{9} \mathrm{CF}$, Art. 182. A política de desenvolvimento urbano, executada pelo Poder Público municipal, conforme diretrizes gerais fixadas em lei, tem por objetivo ordenar o pleno desenvolvimento das funções sociais da cidade e garantir o bem- estar de seus habitantes.

(...)

$\S 2^{\circ}$ - A propriedade urbana cumpre sua função social quando atende às exigências fundamentais de ordenação da cidade expressas no plano diretor.
}

(C) 2008. Departamento de Direito da UFSM. Todos os direitos reservados. 
Partindo-se dos valores consagrados na Constituição Federal, coube à legislação infra-constitucional, a regulamentação do direito de propriedade e, portanto, dos mecanismos de efetivação de sua finalidade social. Nesse quadro, evidencia-se o papel do Município, que, como pessoa jurídica com capacidade política, recebeu atribuições essenciais ao implemento das premissas constitucionais.

No que tange à propriedade urbana, tem-se as previsões do Estatuto da Cidade, o qual introduziu mecanismos inovadores e de grande relevância para que seja possível o desenvolvimento urbano segundo os ditames da Carta Magna, tais como IPTU progressivo no tempo, preempção, outorga onerosa do direito de construir, possibilidade de alteração do uso do solo, a desapropriação-sanção com fins urbanísticos e, seguindo previsão constitucional, a regulamentação da usucapião especial de imóvel urbano. Desse modo, percebe-se um esforço legislativo inovador, no sentido de que as cláusulas constitucionais tenham aplicação efetiva.

Outrossim, o Estatuto da Cidade traçou as diretrizes e disposições obrigatórias a constar no Plano Diretor municipal. Este, por sua vez, traça as exigências fundamentais a serem atendidas pela propriedade urbana, de forma a obter-se a finalidade social almejada na Carta Política.

Nesta senda, pode-se afirmar que, se ainda em muitos aspectos os preceitos constitucionais carecem de regulamentação legislativa que possibilite uma real implementação, não se vislumbra esta indesejada realidade no referente ao tratamento da propriedade urbana, notadamente no concernente à sua finalidade social.

Assim, cabe ao Poder Público zelar pela aplicação de disposições legislativas de inegável qualidade, de modo que estas não se tornem letra morta e, principalmente, possibilitem um desenvolvimento desejável e ordenado das cidades brasileiras. 


\section{REFERÊNCIAS BIBLIOGRÁFICAS}

SILVA, José Afonso da. Direito Urbanístico Brasileiro. $4^{\mathrm{a}}$ ed. São Paulo : Malheiros Editores, 2000.

LAKATOS, Eva Maria e MARCONI, Marina de Andrade. Fundamentos de Metodologia Científica. 6a ed. São Paulo: Atlas, 2007.

MEIRELLES, Hely Lopes. Direito Municipal Brasileiro. 9ª ed. São Paulo: Malheiros Editores, 1997.

PREFEITURA MUNICIPAL DE SANTA MARIA. Plano Diretor de Desenvolvimento Urbano e Ambiental. Santa Maria-RS. Disponível em: <http://santamaria.gov.br/plano diretor>. Acesso em: março de 2008

MEDAUER, Odete e ALMEIDA, Fernando Dias Menezes (organização). Estatuto da Cidade - Lei 10.257/01 Comentários. Editora Revista dos Tribunais. São Paulo, 2002.

FILHO, José dos Santos Carvalho. Manual de Direito Administrativo.19 Edição. Editora Lúmen Júris. Rio de Janeiro, 2008. 